\title{
Persepsi Siswa atas Kompetensi Sosial Guru dan Minat Belajar terhadap Prestasi Belajar Matematika
}

Asmar

Universitas Indraprasta PGRI Jakarta

\begin{abstract}
INFO ARTICLES
Article History:

Received: 25 Januari 2018

Revised: 7 Februari 2018

Approved: 14 Februari 2018

Publish Online: 21 Februari 2018

Key Words:

students' perception, learning interest

Abstract: The purpose of this study was to determine the impacts of student's perception on teacher's social competence and learning interest on mathematics learning achievement. The research was conducted on students of class VII in Imanuel Junior High School and Pa Van Des Teur Junior High School, Pondok Melati, East Jakarta. This study is corelasional survey research with regression analysis. Based on research results, it can be concluded that both of student's perception on teacher's social competence and learning interest give positive influence and significantly on mathematics learning achievement and also together student's perception on teacher's social competence and learning interests give positive impacts and significantly on mathematics learning achievement.

Abstrak: Tujuan penelitian untuk mengetahui pengaruh persepsi siswa atas kompetensi sosial guru dan minat belajar terhadap prestasi belajar matematika. Penelitian dilaksanakan pada siswa kelas VII di SMP Imanuel dan SMP Pa Van Des Teur, Pondok Melati, Jakarta Timur merupakan penelitian survei korelasional dengan analisis regresi ganda. Berdasarkan hasil penelitian, diperoleh simpulan bahwa baik persepsi siswa atas kompetensi sosial guru maupun minat belajar memberikan pengaruh positif dan signifikan terhadap prestasi belajar matematika, bagitu juga secara bersama-sama persepsi siswa atas kompetensi sosial guru dan minat belajar juga memberikan pengaruh positif dan signifikan terhadap prestasi belajar matematika.
\end{abstract}

\footnotetext{
Correspondence Address: J1. Raya Tengah No. 80, Gedong, Pasar Rebo, Jakarta Timur ; e-mail: asmar.unindra@gmail.com

How to Cite (APA $6^{\text {th }}$ Style): Asmar. (2018). Persepsi Siswa atas Kompetensi Sosial Guru dan Minat Belajar terhadap Prestasi Belajar Matematika. JKPM (Jurnal Kajian Pendidikan Matematika), Vol.3 (2), 105-114
}

Copyright: Asmar, (2018)

Competing Interests Disclosures: The authors declare that they have no significant competing financial, professional or personal interests that might have influenced the performance or presentation of the work described in this manuscript. 


\section{PENDAHULUAN}

Guru menyadari peranan yang dipegangnya dalam pertemuan dengan siswa cukup berat. Berperan sebagai guru mengandung tantangan, karena disatu pihak guru harus ramah, sabar, menunjukkan pengertian, memberikan kepercayaan dan menciptakan suasana aman. Sementara dilain pihak, guru harus memberikan tugas, mendorong siswa untuk berusaha mencapai tujuan, mengadakan koreksi, menegur dan menilai. Sebelum proses belajar-mengajar dimulai, guru harus memiliki kemampuan dan kerelaan untuk memaklumi alam pikiran dan perasaan siswa. Guru harus bersedia untuk menerima siswa seadanya,akan tetapi, sekaligus pula guru harus mendekati siswa secara kritis, karena siswa tidak dapat dibiarkan dalam keadaanya yang sekarang.

Persepsi siswa terhadap guru sangat berpengaruh karena, "Semua siswa mengetahui dari pengalaman sendiri, bahwa guru berperan sekali dalam keseluruhan proses belajar didalam kelas. Siswa mengharapkan banyak sekali dari guru. Bila harapan itu dipenuhi, siswa akan merasa puas, bila tidak dia akan merasa kecewa." (Winkel, 2009: 218). Ada sejumlah kemampuan yang belum dimiliki siswa dan mereka harus dibantu untuk memperolehnya, bahkan ada kekurangan dalam bersikap dan cara bertindak siswa yang harus diperbaiki. Kepribadian guru seolah-olah terbelah menjadi dua bagian: disatu pihak bersikap empatik, dilain pihak bersikap kritis: disatu pihak menerima, dilain pihak menolak.

Pemerintah sangat menyadari peranan pendidik yang tercermin dalam pasal 28 Peraturan Pemerintah Nomor 19 Tahun 2005, disebutkan bahwa pendidik adalah agen pembelajaran yang harus memiliki empat jenis kompetensi, yakni kompetensi pedagogik, kepribadian, profesional, dan sosial. Disisi lain,minat belajar merupakan salah satu faktor yang kuat untuk memeroleh prestasi belajar, khususnya prestasi belajar matematika. Karena ketertarikan siswa inilah yang merupakan salah satu tanda-tanda minat. Minat itu tidak muncul dengan sendirinya akan tetapi banyak faktor yang dapat mempengaruhi munculnya minat. Ada beberapa faktor yang dapat mempengaruhi minat belajar siswa antara lain: 1) Motivasi, 2) Belajar, 3) Bahan pengajaran dan Sikap Guru, 4) Keluarga, 5) Teman Pergaulan, 6) Lingkungan, 7) Cita-cita, 8) Bakat, 9) Hobi, 10) Media Massa.

Kemampuan belajar yang dimiliki manusia, merupakan bekal yang sangat pokok. Berdasarkan kemampuan itu, umat manusia telah berkembang selama abad-abad yang lalu dan tetap terbuka kesempatan luas baginya untuk memperkaya diri dan mencapai taraf kebudayaan yang lebih tinggi. Misalnya para ahli teknologi berusaha terus untuk menemukan sumber-sumber energi yang baru, dengan mempergunakan hasil penemuan ilmiah yang telah digali oleh generasi-generasi terdahulu. Namun, tanpa dibekali kemampuan belajar, kemajuan di bidang teknologi ini tidak mungkin.

Berdasarkan kesadaran tentang peranan belajar dalam perkembangan anak didik, masyarakat modern mendirikan lembaga-lembaga yang secara khusus bertugas mengatur pengalaman belajar dengan sedemikian baiknya, sehingga menunjang perkembangan anak didik dan tidak mengghambatnya. Lembaga itu yang disebut "sekolah" atau "institusi pendidikan formal". Maka pendidik disekolah mutlak perlu memahami apa itu "belajar", memaklumi faktor-faktor yang berperan di dalam belajar, menguasai tata-cara mengatur proses belajar dan menentukan aneka sarana yang menunjang proses belajar itu. Makin luas dan dalam pengetahuan pendidik di sekolah mengenai "belajar", makin besarlah harapan dia akan berhasil dalam menunaikan tugasnya sebagai agen pembelajaran dengan empat jenis kompetensi yang keseluruhannya baik.

Matematika merupakan ilmu universal yang mendasari perkembangan teknologi modern, mempunyai peran penting dalam berbagai disiplin dan memajukan daya pikir manusia. Perkembangan pesat di bidang teknologi informasi dan komunikasi dewasa ini dilandasi oleh perkembangan matematika di bidang teori 
bilangan, aljabar, analisis, teori peluang dan matematika diskrit. Untuk menguasai dan mencipta teknologi di masa depan diperlukan penguasaan matematika yang kuat sejak dini.

Mata pelajaran Matematika perlu diberikan kepada semua siswa mulai dari sekolah dasar untuk membekali siswa dengan kemampuan berpikir logis, analitis, sistematis, kritis, dan kreatif, serta kemampuan bekerjasama. Kompetensi tersebut diperlukan agar siswa dapat memiliki kemampuan memeroleh, mengelola, dan memanfaatkan informasi untuk bertahan hidup pada keadaan yang selalu berubah, tidak pasti, dan kompetitif.

Mata pelajaran Matematika merupakan mata pelajaran yang mengembangkan kemampuan berkomunikasi dengan menggunakan bilangan dan simbol-simbol serta ketajaman penalaran yang dapat membantu memperjelas dan menyelesaikan permasalahan dalam kehidupan sehari-hari. Namun umumnya siswa menganggap bahwa Matematika adalah salah satu mata pelajaran yang dianggap sukar di sekolah dan bahkan ditakuti. Hal tersebut terjadi dimungkinkan karena siswa kurang bersikap kreatif dan kemungkinan kurang atau bahkan tidak membiasakan belajar matematika dengan baik.

Kompetensi guru dalam melaksanakan pembelajaran senantiasa menjadi perhatian siswa pembelajar, karena proses pembelajaran merupakan interaksi keduannya. Kemampuan dalam mengajar secara turun dan sistematis serta membangkitkan gairah baik secara model dan pendekatannya sangat diperlukan oleh siswa, karena hal tersebut akan sangat membantu ketertarikan dan antusias siswa. Ketika guru memberikan apa yang diharapkan oleh siswa, secara psikologis siswa akan merasa dekat sehingga ketakutan dan kehawatirannya akan hilang dalam mempelajari materi yang dianggap sulit pun. Berdasarkan hal tersebut penulis tertarik untuk melakukan penelitian lebih lanjut mengenai : "Pengaruh Persepsi Siswa Tentang Kompetensi Sosial Guru dan Minat Belajar Siswa terhadap Prestasi Belajar Matematika".

\section{METODE}

Penelitian ini dilaksanakan pada siswa kelas VII di SMP Imanuel dan SMP Pa Van Des Teur, Pondok Melati, Jakarta Timur. Penelitian yang dilaksanakan pada bulan Juli s.d. September ini merupakan penelitian survai korelasional dengan analisis regresi ganda. Adapun desain penelitian digambarkan sebagai berikut:

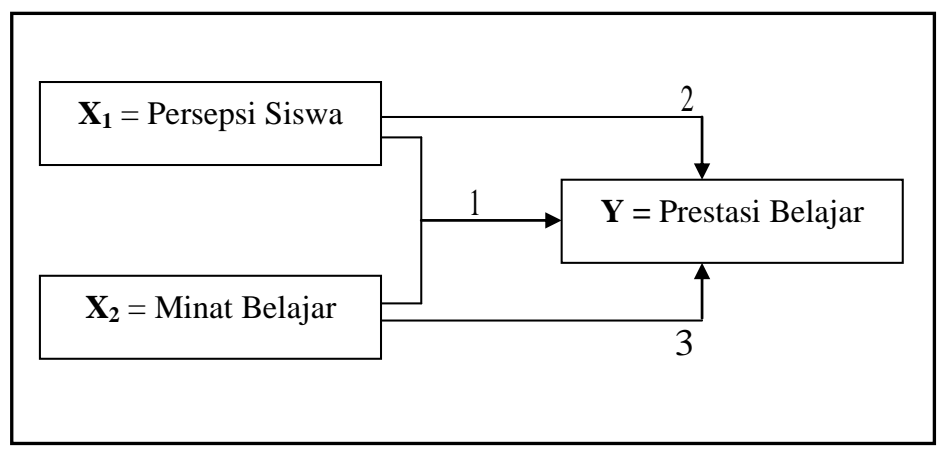

Gambar 1. Desain Penelitian

Keterangan:

$\mathrm{X}_{1}$ : Persepsi Siswa

$\mathrm{X}_{2}$ : Minat Belajar Siswa

Y : Prestasi Belajar Matematika

1 : Pengaruh Persepsi Siswa dan Minat Belajar Siswa Secara Bersama-sama terhadap Prestasi Belajar Matematika 
2 : Pengaruh Persepsi Siswa terhadap Prestasi Belajar Matematika

3 : Pengaruh Minat Belajar Siswa terhadap Prestasi Belajar Matematika

Populasi target dari penelitian ini adalah seluruh siswa-siswi SMP Imanuel dan SMP Pa Van Des Teur tahun ajaran 2013/2014. Adapun Populasi terjangkau dari penelitian ini adalah seluruh siswa kelas VII SMP Imanuel dan SMP Pa Van Des Teur, yang terdaftar pada tahun ajaran 2013/2014. Pengambilan sampel penelitian dipilih secara acak sederhana atau simple random sampling. Setelah pengundian, sampel yang digunakan dalam penelitian ini adalah 60 orang siswa.

Pada penelitian ini, ada tiga jenis data yang dikumpulkan, dimanaketiga sumber data tersebut didasarkan pada tiga variabel penelitian, yakni data tentang variabel bebas $\left(\mathrm{X}_{1}\right)$ yaitu:"Persepsi Siswa tentang Kompetensi Sosial Guru", variabel bebas $\left(\mathrm{X}_{2}\right)$ yaitu:"Minat Belajar Siswa", dan variabel terikat $(\mathrm{Y})$ yaitu:"Prestasi Belajar matematika". Instrumen penelitian yang digunakan untuk mengumpulkan data "Persepsi Siswa tentang Kompetensi Sosial Guru dan Minat Belajar Siswa" dijaring dengan menggunakan angket atau kuesioner.Adapun data "Prestasi Belajar Matematika Siswa" diambil dari data dokumen. Instrumen penelitian divalidasi secara empiris, dimana instrumen diujicobakan ke 30 orang siswa yang tidak masuk dalam sampel penelitian.

Teknik analisis terhadap data hasil penelitian yang dalam hal ini berupa nilai "Prestasi Belajar Matematika Siswa" serta perolehan total skor atas angket "Persepsi Siswa tentang Kompetensi Sosial Guru" dan "Minat Belajar Siswa" dilakukan secara deskriptif dan inferensial. Secara deskriptif, data hasil penelitian dianalisis untuk skor mean, median, dan modus. Adapun maksud analisis skor mean, median, dan modus adalah untuk mendeskripsikan perolehan ukuran pemusatan data dari siswa sebagai sampel penelitian. Secara inferensial, data hasil penelitian dianalisis menggunakan uji-F dan uji-t, dengan terlebih dahulu diuji untuk persyaratan analisisnya yaitu uji normalitas, uji linearitas, dan uji multikolinearitas. Perhitungan data hasil penelitian secara keseluruhan dilakukan dengan menggunakan bantuan software SPSS.

\section{HASIL}

Data hasil penelitian ini dianalisis secara deskriptif dan inferensial. Secara deskriptif, data hasil penelitian ini ditampilkan dalam tabel di bawah ini:

Tabel 1. Ringkasan Hasil Perhitungan Statistik Deskriptif

\begin{tabular}{lccc}
\hline \multicolumn{1}{c}{ Kelompok } & Mean & Median & Modus \\
\hline Prestasi Belajar Matematika & 75,06 & 75,00 & 75,00 \\
Persepsi Siswa tentang Kompetensi Sosial Guru & 79,88 & 80,50 & 82,00 \\
Minat Belajar Siswa & 65,48 & 66,00 & 69,00 \\
\hline
\end{tabular}

Sumber: Data primer yang diolah

Berdasarkan Tabel 1, diperoleh informasi untuk variabel prestasi belajar matematika siswa bahwa skor mean, median, dan modus relatif sama yang berada di satu titik yakni kisaran angka 75. Hal ini berarti, kurva distribusi frekuansi akan terbentuk simetris, yang maknanya adalah frekuensi dari skor prestasi belajar matematika yang tinggi dan rendah relatif sama. Kemudian berdasarkan tabel 1 juga, dapat diperoleh informasi bahwa skor mean, median, dan modus untuk variabel kecerdasan spiritual siswa tidaklah sama, dimana skor mean lebih kecil dari skor median, dan skor median lebih kecil dari skor modus. Hal ini berarti, kurva distribusi frekuensi akan terbentuk miring ke kiri, yang maknanya adalah akan ada frekuensi lebih 
rendah dari skor kecerdasan spiritual yang tinggi dan frekuensi lebih tinggi dari skor kecerdasan spiritual yang rendah. Informasi terakhir berdasarkan tabel 1 juga diperoleh bahwa skor mean, median, dan modus untuk variabel sikap siswa pada pelajaran matematika tidaklah sama, dimana skor mean lebih kecil dari skor median, dan skor median lebih kecil dari skor modus. Hal ini juga berarti, kurva distribusi frekuansi sikap siswa pada pelajaran matematika akan terbentuk miring ke kiri, yang maknanya adalah akan ada frekuensi lebih rendah dari skor tinggi untuk sikap siswa pada pelajaran matematika dan frekuensi lebih tinggi dari skor rendah sikap siswa pada pelajaran matematika.

Selanjutnya data hasil penelitian dianalisis secara inferensial untuk pengujian hipotesis, namun terlebih dahulu harus dilakukan uji persyaratan analisis data, yang meliputi uji normalitas, uji linearitas, dan uji multikolinearitas. Pengujian normalitas dilakukan untuk mengetahui normal atau tidaknya distribusi data yang akan dianalisis. Perhitungan untuk uji normalitas data dilakukan dengan uji Kolmogorof Smirnof. Kriteria pengujiannya adalah jika nilai probabilitas atau asymp. sig. (2-tailed) $>0,05$ (dalam penelitian ini menggunakan $\alpha=5 \%$ ), maka dinyatakan data berasal dari populasi berdistribusi normal. Berdasarkan tabel 2, terlihat bahwa kelompok sampel yang diteliti memiliki nilai probabilitas atau asymp. sig. (2-tailed) > 0,05 , sehingga dapat disimpulkan bahwa data dari ketiga variabel dalam penelitian ini berasal dari populasi berdistribusi normal.

Tabel 2. Ringkasan Hasil Uji Normalitas

\begin{tabular}{|c|c|c|}
\hline Variabel & $\begin{array}{l}\text { Kolmogorov- } \\
\text { Smirnov Z }\end{array}$ & $\begin{array}{c}\text { Asymp. Sig. } \\
\text { (2-tailed) }\end{array}$ \\
\hline Prestasi Belajar Matematika & 0,999 & 0,271 \\
\hline Persepsi Siswa tentang Kompetensi Sosial Guru & 0,761 & 0,608 \\
\hline Minat Belajar Siswa & 0,665 & 0,769 \\
\hline
\end{tabular}

Sumber: Data primer yang diolah

Setelah uji normalitas data, selanjutnya dilakukan uji persyaratan analisis untuk uji linearitas. Pengujian linearitas dimaksudkan untuk mengetahui apakah dua variabel berpola linear antara satu sama lainnya. Dengan kata lain, uji linearitas dilakukan dalam rangka menguji model persamaan suatu variabel terikat atas suatu variabel bebas. Kriteria pengujiannya adalah kedua variabel dikatakan berpola linear jika nilai sig. linearity< 0,05 (dalam penelitian ini menggunakan $\alpha=5 \%$ ). Oleh karena pada penelitian ini terdapat satu variabel terikat $(\mathrm{Y})$ dan dua variabel bebas $\left(\mathrm{X}_{1}\right.$ dan $\left.\mathrm{X}_{2}\right)$, maka ada dua uji linearitas. Pertama uji linearitas $\mathrm{X}_{1}$ terhadap $\mathrm{Y}$, yang mana berdasarkan tabel 3, terlihat bahwa nilai sig. linearity< 0,05 , sehingga dapat disimpulkan bahwa terdapat hubungan yang linear antara persepsi siswa tentang kompetensi sosial guru $\left(\mathrm{X}_{1}\right)$ dengan prestasi belajar matematika $(\mathrm{Y})$. 
Tabel 3. Ringkasan Hasil Uji Linearitas Persepsi Siswa tentang Kompetensi Sosial Guru terhadap Prestasi Belajar Matematika

\begin{tabular}{llccccc}
\hline & Model & Sum of Squares & Df & Mean Square & $F$ & Sig. \\
\hline 1 & Regression & 11822.546 & 1 & 11822.546 & 131.222 & .000 \\
& Residual & 11532.262 & 128 & 90.096 & & \\
& Total & 23354.808 & 129 & & & \\
\hline
\end{tabular}

Sumber: Data primer yang diolah

Kedua, uji linearitas $\mathrm{X}_{2}$ terhadap $\mathrm{Y}$, yang mana berdasarkan tabel 4, terlihat bahwa nilai sig. Linearity $<0,05$, sehingga dapat disimpulkan bahwa terdapat hubungan yang linear antara minat belajar siswa $\left(\mathrm{X}_{2}\right)$ dengan prestasi belajar matematika (Y).

Tabel 4. Ringkasan Hasil Uji Linearitas Minat Belajar Siswa terhadap Prestasi Belajar Matematika

\begin{tabular}{llccccc}
\hline & Model & Sum of Squares & $d f$ & Mean Square & $F$ & Sig. \\
\hline 1 & Regression & 5338.305 & 1 & 5338.305 & 37.927 & .000 \\
& Residual & 18016.503 & 128 & 140.754 & & \\
& Total & 23354.808 & 129 & & & \\
\hline
\end{tabular}

Sumber: Data primer yang diolah

Setelah uji linearitas terpenuhi, selanjutnya dilakukan uji persyaratan yang terakhir yaitu uji multikolinearitas. Uji multikolinearitas dimaksudkan untuk mengetahui hubungan antar variabel bebas yaitu ada atau tidaknya hubungan yang kuat antara variabel persepsi siswa tentang kompetensi sosial guru $\left(\mathrm{X}_{1}\right)$ dengan minat belajar siswa $\left(\mathrm{X}_{2}\right)$. Kriteria pengujiannya adalah kedua variabel bebas tidak terdapat masalah multikolinearitas jika nilai Variance Inflation Factor (VIF) $<10$. Berdasarkan tabel 5, terlihat bahwa nilai Variance Inflation Factor (VIF) < 10, berarti variabel terbebas dari asumsi klasik multikolinearitas atau dengan kata lain kedua variabel bebas tidak terdapat masalah multikolinearitas.

\begin{tabular}{llcc}
\multicolumn{2}{l}{ Tabel 5. Ringkasan Hasil Uji Multikolinearitas } \\
\hline \multicolumn{2}{l}{ Model } & \multicolumn{2}{c}{ Collinearity } \\
& & Statistics \\
& & Tolerance & VIF \\
\hline 1 & PERSEPSI & .849 & 1.177 \\
& MINAT & .849 & 1.177 \\
\hline
\end{tabular}

Sumber: Data primer yang diolah

Setelah semua uji persyaratan analisis terpenuhi, dilanjutkan dengan pengujian hipotesis, yaitu: (1) uji pengaruh persepsi siswa tentang kompetensi sosial guru $\left(\mathrm{X}_{1}\right)$ dan minat belajar siswa $\left(\mathrm{X}_{2}\right)$ secara bersamasama terhadap prestasi belajar matematika(Y), (2) uji pengaruh persepsi siswa tentang kompetensi sosial guru $\left(\mathrm{X}_{1}\right)$ terhadap prestasi belajar matematika $(\mathrm{Y})$, dan (3) uji pengaruh minat belajar siswa $\left(\mathrm{X}_{2}\right)$ terhadap prestasi belajar matematika (Y). 
Tabel 6. Ringkasan Hasil Uji Korelasi $\mathrm{X}_{1}$ dan $\mathrm{X}_{2}$ terhadap $\mathrm{Y}$

\begin{tabular}{lcccc}
\hline \multicolumn{2}{l}{$\begin{array}{l}\text { Model Summary } \\
\text { Model }\end{array}$} & $R$ & $R$ & Adjusted $R$ \\
& & Square & Square & $\begin{array}{c}\text { Std. Error of } \\
\text { the Estimate }\end{array}$ \\
\hline 1 & $.744^{\mathrm{a}}$ & .554 & .547 & 9.054 \\
\hline
\end{tabular}

Sumber: Data primer yang diolah

Tabel 7. Ringkasan Hasil Uji $F$ untuk Pengujian

Pengaruh Simultan $\mathrm{X}_{1}$ dan $\mathrm{X}_{2}$ terhadap $\mathrm{Y}$

\begin{tabular}{|c|c|c|c|c|c|c|}
\hline \multicolumn{7}{|c|}{$A N O V A^{\mathrm{b}}$} \\
\hline \multirow[t]{3}{*}{1} & Regression & 12943.103 & 2 & 6471.551 & 78.939 & $000^{a}$ \\
\hline & Residual & 10411.705 & 127 & 81.982 & & \\
\hline & Total & 23354.808 & 129 & & & \\
\hline
\end{tabular}

Sumber: Data primer yang diolah

Tabel 8. Ringkasan Hasil Uji $t$ untuk Pengujian

Pengaruh $\mathrm{X}_{1}$ terhadap Y dan Pengaruh $\mathrm{X}_{2}$ terhadap $\mathrm{Y}$

\begin{tabular}{|c|c|c|c|c|c|c|}
\hline \multicolumn{7}{|c|}{ Coefficients ${ }^{\mathrm{a}}$} \\
\hline & \multirow[t]{2}{*}{ Model } & \multicolumn{2}{|c|}{$\begin{array}{c}\text { Unstandardized } \\
\text { Coefficients }\end{array}$} & \multirow{2}{*}{$\begin{array}{c}\text { Standardized } \\
\text { Coefficients } \\
\text { Beta }\end{array}$} & \multirow[t]{2}{*}{$t$} & \multirow[t]{2}{*}{ Sig. } \\
\hline & & $B$ & $\begin{array}{l}\text { Std. } \\
\text { Error }\end{array}$ & & & \\
\hline \multirow[t]{3}{*}{1} & (Constant) & -10.572 & 6.963 & & -1.518 & .131 \\
\hline & PERSEPSI & .886 & .092 & 619 & 9.631 & .000 \\
\hline & MINAT & .240 & .065 & .238 & 3.697 & .000 \\
\hline
\end{tabular}

Sumber: Data primer yang diolah

Uji Hipotesis Pertama, yaitu: "Pengaruh Persepsi Siswa tentang Kompetensi Sosial Guru dan Minat Belajar Siswa Secara Bersama-sama terhadap Prestasi Belajar Matematika" Korelasi ganda yang menghubungkan persamaan kecerdasan spiritual, sikap siswa pada pelajaran matematika, dan prestasi belajar matematika diperoleh dari tabel 6. Berdasarkan tabel 6, diperoleh hasil korelasi kecerdasan spiritual dan sikap siswa secara bersama-sama dengan prestasi belajar matematika adalah 0.744; yang berarti korelasi antara ketiga variabel tersebut tergolong kuat. Koefisien determinasinya sebesar 0,554 atau ada kontribusi sebesar 55,4\% berupa pengaruh kecerdasan spiritual dan sikap siswa secara bersama-sama terhadap prestasi belajar matematika. Pengujian signifikansi korelasi menggunakan koefisien sig, dimana sig=0,000; yang artinya korelasi antara ketiga variabel tersebut signifikan.

Selanjutnya adalah pengujian hipotesis regresi ganda $\mathrm{X}_{1}$ dan $\mathrm{X}_{2}$ terhadap $\mathrm{Y}$ dengan uji $\mathrm{F}$. Adapun kriteria pengujiannya adalah $\mathbf{H}_{0}$ diterima jika $F_{\text {hitung }}<F_{\text {tabel }}$ atau $H_{0}$ ditolak jika $F_{h i t u n g}>F_{\text {tabel. }}$ Setelah dilakukan perhitungan, diperoleh nilai $\mathrm{F}$ seperti pada tabel 7. Berdasarkan tabel 7, diperoleh nilai $\mathrm{F}_{\text {hitung }}=$ 78,939. Adapun dengan $\mathrm{dk}_{1}=2$ dan $\mathrm{dk}_{2}=127$ diperoleh nilai $\mathrm{F}_{\text {tabel }}=3,067$. Oleh karena $F_{\text {hitung }}>F_{\text {tabel }}$ maka $\mathbf{H}_{0}$ ditolak. Hal ini berarti bahwa $\mathbf{H}_{\mathbf{0}}$ (hipotesis nol) yang menyatakan tidak terdapat pengaruh yang signifikan kecerdasan spiritual dan sikap siswa secara bersama-sama terhadap prestasi belajar matematika adalah ditolak. Dengan demikian, hipotesis pada penelitian ini yang berbunyi: "terdapat pengaruh yang 
signifikan kecerdasan spiritual dan sikap siswa secara bersama-sama terhadap prestasi belajar matematika" adalah diterima. Dengan kata lain, dapat disimpulkan bahwa terdapat pengaruh yang signifikan kecerdasan spiritual dan sikap siswa secara bersama-sama terhadap prestasi belajar matematika.

Adapun persamaan regresi ganda yang diperoleh berdasarkan hasil penelitian ini dapat disusun berdasarkan tabel 8. Berdasarkan tabel 8, dapat disusun persamaan regresi ganda $\widehat{\mathbf{Y}}=-10,572+$ $0,886 \mathbf{X}_{1}+0,240 \mathbf{X}_{2}$. Adapun persamaan regresi ganda tersebut dapat diinterpretasikan sebagai berikut: Konstanta sebesar $-10,572$ menyatakan bahwa jika tidak ada kecerdasan spiritual dan sikap siswa pada pelajaran matematika maka prestasi belajar matematika siswa diperoleh sebesar 10,572. Atau dengan kata lain prestasi belajar matematika siswa diperoleh sebesar 10,572 jika kecerdasan spiritual dan sikap siswa pada pelajaran matematika diabaikan.

Koefisien regresi $\mathrm{X}_{1}$ (persepsi siswa tentang kompetensi sosial guru) sebesar 0,886 menyatakan bahwa setiap penambahan 1 satuan, kecerdasan spiritual siswa akan meningkatkan prestasi belajar matematika sebesar 0,886 dengan anggapan $\mathrm{X}_{2}$ (minat belajar siswa) tetap. Berlaku juga sebaliknya, jika kecerdasan spiritual siswa turun 1 satuan, maka prestasi belajar matematika diprediksi mengalami penurunan sebesar 0,886 dengan anggapan $\mathrm{X}_{2}$ (minat belajar siswa) tetap.

Koefisien regresi $\mathrm{X}_{2}$ (minat belajar siswa) sebesar 0,240 menyatakan bahwa setiap penambahan 1 satuan, sikap siswa pada pelajaran matematika akan meningkatkan prestasi belajar matematika sebesar 0,240 dengan anggapan $X_{1}$ (persepsi siswa tentang kompetensi sosial guru) tetap. Berlaku juga sebaliknya jika sikap siswa pada pelajaran matematika turun 1 satuan, maka prestasi belajar matematika diprediksi mengalami penurunan sebesar 0,240 dengan anggapan $X_{1}$ (persepsi siswa tentang kompetensi sosial guru) tetap.

Uji Hipotesis Kedua, yaitu: "Pengaruh Persepsi Siswa tentang Kompetensi Sosial Guru terhadap Prestasi Belajar Matematika" Kemudian nilai $\boldsymbol{t}$ seperti tampak pada tabel 8, yang mana diperoleh nilai

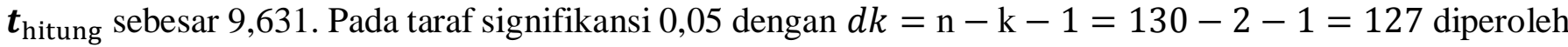
$\boldsymbol{t}_{\text {tabel }}=1$ 1,960. Dengan demikian $H_{0}$ ditolak karena $\left|t_{\text {hitung }}\right|>t_{\text {tabel }}(9,631>1,960)$, hal ini berarti terdapat pengaruh yang signifikan persepsi siswa tentang kompetensi sosial guru terhadap prestasi belajar matematika.

Uji Hipotesis Ketiga, yaitu: "Pengaruh Minat Belajar Siswa terhadap Prestasi Belajar Matematika" Berikutnya tertera pada tabel 8, nilai $\boldsymbol{t}_{\mathrm{hitung}}$ sebesar 3,697. Pada taraf signifikansi 0,05 dengan $d k=\mathrm{n}-$ $\mathrm{k}-1=130-2-1=127$ diperoleh $\boldsymbol{t}_{\text {tabel }}=1,960$. Dengan demikian $\mathrm{H}_{0}$ ditolak karena $\left|t_{\text {hitung }}\right|>$ $t_{\text {tabel }}(3,697>1,960)$, hal ini berarti terdapat pengaruh yang signifikan minat belajar siswa terhadap prestasi belajar matematika.

\section{HASIL}

Pembahasan hasil penelitian terkait pengaruh simultan persepsi siswa tentang kompetensi sosial guru dan minat belajar siswa terhadap prestasi belajar matematika, hasil penelitian memberikan hasil signifikan, artinya secara bersama-sama kedua variabel bebas (persepsi siswa dan minat belajar) mempunyai pengaruh yang cukup besar bagi variasi prestasi belajar. Persepsi siswa merupakan hal yang penting karena pandangan seorang individu terhadap individu lain tidaklah selalu sesuai dengan kenyataan yang sebenarnya. Orang cenderung melihat orang lain sebagaimana yang diinginkan. Sebenarnya individu tidak melihat realitas tetapi menginterprestasikan realitas, dan orang bertingkah laku atas dasar persepsi mereka masing - masing (Slameto, 2010). 
Dengan memiliki persepsi siswa, seseorang dapat memandang segala sesuatu dari kacamata yang baik. Suasana hatinya tidak mudah berubah apabila menghadapi suasana-suasana yang tidak baik. Persepsi dan minatnya tidak serta merta berubah akibat guru, orang tua, teman, dan atau lingkungannya memberikan tekanan negatif kepada dirinya. Minat akan tumbuh apabila kita berusaha mencari berbagai keterangan selengkap mungkin mengenai mata pelajaran itu, umpamanya arti penting atau pesonanya dan segi-segi lainnya yang mungkin menarik. Keterangan itu dapat diperoleh dari buku pegangan. ensiklopedi, guru dan siswa senior yang tertarik atau berminat pada mata pelajaran itu.

Prestasi belajar matematika adalah kemampuan yang dimiliki siswa setelah ia menerima pengalaman belajarnya. Prestasi Belajar mempunyai peranan penting dalam proses pembelajaran. Proses penilaian terhadap Prestasi Belajar dapat memberikan informasi kepada guru tentang kemajuan siswa dalam upaya mencapai tujuan-tujuan belajarnya melalui kegiatan belajar (Sudjana, 2010). Dalam belajar, tentu ada sesutu yang ingin dicapai yaitu hasil belajar atau suatu keberhasilan yang maksimal. Keberhasilan atau prestasi belajar ditentukan oleh interaksi berbagai faktor yaitu faktor yang bersumber dari dalam diri (internal) maupun dari luar (eksternal) individu. Faktor internal meliputi keadaan fisik dan psikis individu secara umum, sedangkan faktor eksternal meliputi keadaan lingkungan sekitar yang dapat mempengaruhi proses belajar.

Hasil penelitian membuktikan bahwa minat belajar memberikan kontribusi positif terhadap prestasi belajar matematika, atau dalam arti lain minat belajar menjadi faktor penentu keberhasilan dalam belajar. Diharapkan dengan memiliki minat belajar dan persepsi siswa yang tinggi, seorang siswa mampu mengatasi setiap tantangan dalam proses pembelajaran, terutama yang berhubungan dengan kemampuan bersosialisasi dan bermasyarakat.

Sedangkan terkait pengaruh persepsi siswa tentang kompetensi sosial guru terhadap prestasi belajar matematika, hasil penelitian memberikan hasil signifikan, yang artinya membuktikan bahwa ada pengaruh minat dan signifikan persepsi siswa terhadap prestasi belajar. Persepsi siswa merupakan pengalaman tentang obyek, peristiwa atau hubungan-hubungan yang diperoleh dengan mengumpulkan informasi dan menafsirkan pesan. Persepsi adalah memberikan makna pada stimuli atau merangasang indrawi. Dengan adanya persepsi siswa, seseorang dapat memandang segala sesuatu dari kacamata yang baik. Suasana hatinya tidak mudah berubah apabila menghadapi suasana-suasana yang tidak baik. Konsentrasi dan minatnya tidak serta merta berubah akibat guru, orang tua, teman, dan atau lingkungannya memberikan tekanan negatif kepada dirinya.

Prestasi belajar matematika merupakan perubahan yang dialami siswa baik secara kognitif, afektif, maupun psikomotorik, sebagai hasil pengalaman belajar matematika. Hasil belajar matematika akan meningkat sehubungan dengan kemampuan siswa untuk belajar, berkonsentrasi, dan berlatih. Siswa yang mampu menyediakan waktu untuk belajar, tentunya akan mampu memperoleh hasil belajar yang optimal.

Hasil penelitian telah menemukan bahwa data yang diperoleh memberikan hasil ada pengaruh persepsi siswa terhadap prestasi belajar matematika siswa. Temuan empiris ini memberikan keyakinan bahwa dengan persepsi, siswa mampu mengoptimalkan seluruh kemampuannya dan mereduksi hal-hal negatif yang menimpanya, serta mengubahnya menjadi energi positif yang akan membangkitkan semangatnya untuk belajar.

Dalam bahasan, pengaruh minat belajar siswa terhadap prestasi belajar matematika, hasil penelitian memberikan hasil signifikan, yang artinya membuktikan bahwa ada pengaruh persepsi dan signifikan Minat Belajar terhadap prestasi belajar. Minat belajar merupakan suatu keinginan yang benar-benar ingin dilakukan dengan dorongan motivasi. Minat akan tumbuh apabila kita berusaha mencari berbagai keterangan selengkap mungkin mengenai mata pelajaran itu, umpamanya arti penting atau pesonanya dan segi-segi lainnya yang mungkin menarik. Keterangan itu dapat diperoleh dari buku pegangan. ensiklopedi, guru dan siswa senior yang tertarik atau berminat pada mata pelajaran itu. 
Prestasi belajar matematika adalah perubahan tingkah laku siswa sebagai indikator tingkat ketercapaian tujuan belajar matematika dalam penguasaan struktur kognitif berupa fakta-fakta, konsepkonsep dan generalisasi setelah mendapatkan pengalaman belajar di bidang matematika. Dalam belajar, tentu ada sesutu yang ingin dicapai yaitu hasil belajar atau suatu keberhasilan yang maksimal. Keberhasilan atau prestasi belajar ditentukan oleh interaksi berbagai faktor yaitu faktor yang bersumber dari dalam diri (internal) maupun dari luar (eksternal) individu. Faktor internal meliputi keadaan fisik dan psikis individu secara umum, sedangkan faktor eksternal meliputi keadaan lingkungan sekitar yang dapat mempengaruhi proses belajar. Untuk mengetahui sesorang itu telah belajar perlu adanya suatu penilaian untuk menentukan sesorang tersebut telah mendapatkan hasil belajar yang baik atau belum.

Hasil penelitian membuktikan bahwa minat belajar memberikan kontribusi positif terhadap prestasi belajar matematika, atau dalam arti lain minat belajar menjadi faktor penentu keberhasilan dalam belajar. Diharapkan dengan memiliki minat belajar yang tinggi, seorang siswa mampu mengatasi setiap tantangan dalam proses pembelajaran, terutama yang berhubungan dengan kemampuan bersosialisasi dan bermasyarakat.

\section{PEMBAHASAN}

Berdasarkan hasil analisis data: persepsi siswa dan minat belajar secara bersama-sama memberikan pengaruh positif dan signifikan terhadap prestasi belajar. Persepsi siswa memberikan pengaruh positif dan signifikan terhadap prestasi belajar. Minat belajar memberikan pengaruh negatif, tetapi tidak signifikan terhadap prestasi belajar.

Guru sebagai insan terpelajar, yang memiliki tugas istimewa untuk mencerdaskan insan lainnya, berupaya untuk mencari hal-hal yang dapat membangkitkan persepsi siswa siswa. Seluruh elemen pendidikan, siswa, orangtua, guru dan pemerintah harus mengupayakan agar siswa tetap memiliki motivasi belajar yang baik, dan mengupayakan untuk mengurangi faktor-faktor yang dapat menumbuhkan minat belajar dalam diri siswa, sehingga prestasi belajarnya dapat terus ditingkatkan. Perlu diadakan penelitian lanjutan untuk sampel dan variabel yang lebih besar.

\section{DAFTAR PUSTAKA}

Slameto, 2010. Belajar dan Faktor-Faktor yang Mempengaruhinya. Jakarta: Rineka Cipta. Sudjana, N. 2010. Penilaian Hasil Proses Belajar Mengajar. Jakarta: Rosdakarya. Thobroni. 2011. Belajar dan Pembelajaran. Jakarta: Ar-Ruzz Media. Winkel. 2009. Psikologi Pengajaran. Jakarta: Gramedia. 